Another strain of T. harzianum is used in agriculture as a biocontrol agent to kill soilborne pathogens. De la Fuente says, "I think that the scientific community needs to look at whether this widely used strain of Trichoderma harzianum is not mutating or adapting and causing this disease on mushrooms." However the source of the problem has not been determined.

De la Fuente suspects the new disease arrived last year Santa Clara County because production yields dropped from 145 tons per acre in 1995 to 133 tons per acre in 1996.

California growers may be granted a special use of the fungicide benlate (Benomyl) to treat the planting material, called spawn, to stem the spread of the disease. Currently use of the fungicide on mushrooms is restricted to application after the crop is established. To ease this restric- tion, de la Fuente recently requested the California Department of Pesticide Regulation's endorsement for the petition prepared for the Environmental Protection Agency (EPA) for a Special Local Need Registration Section 24(c) of benlate to treat the spawn before planting. EPA has granted a similar permit to the state of Pennsylvania. One problem with using this fungicide is that there is a high risk of killing the mushroom, itself a fungus. To reduce the risk, she will advise growers to treat the spawn right before planting and to make sure they don't overdose.

"The potential loss for California mushroom farmers because of this disease is sizable," de la Fuente says, "and a benlate spawn treatment will have a significant impact in reducing this threat as it did for Pennsylvania growers." $-E d$.

\title{
Fe $7^{-1}$ Outreach news
}

\section{4-H'ers learn leadership skills}

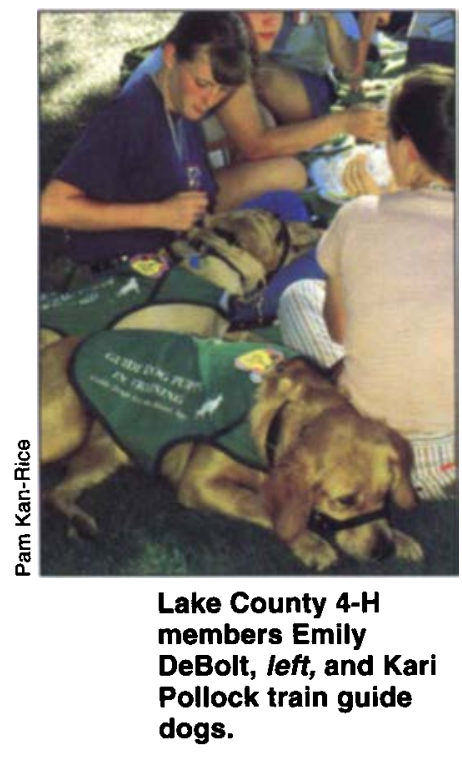

ore than 700 4- $\mathrm{H}$ members gathered in Davis for the annual 4-H State Leadership Conference. Members traveled from all over the state to attend the 3-day event in August.

"One person can make a difference, you can make a difference," keynote speaker Richard Santana, an educator with a master's degree from Harvard University, told the young people. "Someone taught me that I was worth something and I became willing to change," said the former gang member.

The conference theme "4-H Is Not a Spectator Sport" was reflected in 21 how-to sessions that will assist 4- $\mathrm{H}$ members planning community projects.

"The kids and adults - teams of four or five per county - put together plans of action to impact their communities," explains conference education chair Rasjidah Franklin, Alameda County youth development advisor. "The plans range from literacy projects and nutrition education to organizing speakouts, where kids' voices can be heard to influence policy. In L.A. County they are starting a co-op for marketing products that didn't sell at the county fair."

Delegate teams participated in workshops concentrating on citizenship, politics and law; teaching, tutoring and literacy; science and agri- culture; communication, visual and performing arts; cross-cultural communication; and health and fitness. New this year were workshops for training adult $4-\mathrm{H}$ volunteers. In all, 98 workshops were offered.

To learn about science and agriculture, some members visited the California Veterinary Diagnostics lab, where researchers demonstrated modern devices for diagnosing illness in animals. At a landscape architecture lab, others learned how engineers and designers develop plans for communities, wildland areas and the spaces in between. Some members collected samples of wildlife and plants along Putah Creek while others toured a local farm and saw how farms can enhance wildlife habitat.

Several headline speakers rounded out the conference program. Robert Corrigan, president of San Francisco State University and chair of President Clinton's "America Reads" initiative, spoke about literacy, learning and community service. Teacher and entrepreneur John Corcoran, who learned to read when he was 48 , explained why literacy is important for everyone. Pacific Telesis vice president Marshall Cochrane, who manages a $\$ 3.5$ billion real estate portfolio, talked about the leadership skills needed today and in the future. 